University of Nebraska - Lincoln

DigitalCommons@University of Nebraska - Lincoln

Faculty Publications from the Harold W. Manter Laboratory of Parasitology

1967

New Records of the Pigmy Shrew Microsorex hoyi (Baird) in Alaska

Robert L. Rausch

University of Washington, rausch@uw.edu

Follow this and additional works at: https://digitalcommons.unl.edu/parasitologyfacpubs

Part of the Parasitology Commons

Rausch, Robert L., "New Records of the Pigmy Shrew Microsorex hoyi (Baird) in Alaska" (1967). Faculty Publications from the Harold W. Manter Laboratory of Parasitology. 344.

https://digitalcommons.unl.edu/parasitologyfacpubs/344

This Article is brought to you for free and open access by the Parasitology, Harold W. Manter Laboratory of at DigitalCommons@University of Nebraska - Lincoln. It has been accepted for inclusion in Faculty Publications from the Harold W. Manter Laboratory of Parasitology by an authorized administrator of DigitalCommons@University of Nebraska - Lincoln. 


\section{NEW RECORDS OF THE PIGMY SHREW MICROSOREX HOYI (BAIRD) IN ALASKA}

\section{Robert L. Rausch}

The results of extensive trapping ( $c a .7000$ small mammals from the Alaskan mainland) indicate that the pigmy shrew, Microsorex hoyi (Baird), is a comparatively rare mammal in Alaska. From January, 1949, to the present, my co-workers and I have collected only seven specimens. These few animals considerably extend the known geographic range of $M$. hoyi in Alaska.

Collecting data for the specimens we have obtained are as follows: Junction of Taylor and Alaska Highways, 20 January 1949 (sex unknown; 75-23-9; USNM No. 290272) (coll. R. L. Rausch); Magrath, during period 23 August-3 September 1949 (male; preserved in formalin) (coll. P. J. Brandly); Lower Rampart, Porcupine River, 22 July 1951 (sex unknown) (coll. M. Beaver); Lake Clark, near Nondalton, 24 June 1959 (male; 95-3511, $4 \mathrm{gm}$ ) (coll. F. S. L. Williamson); Lake at head of West Fork of Gulkana River, 10 September 1959 (male; 91-30-10) (coll. R. L. Rausch); Nyac, 31 May 1963 (male; 88-29-11, 6-8 gm.; testes $6 \mathrm{~mm}$ ) (coll. L. J. Peyton); Mile 18, Nabesna Road, Wrangell Mountain region, 1 September 1966 (male; 86-29-10, 3.2 gm) (coll. L. M. Shults).

Microsorex eximius ( $=$ M. hoyi eximius) was described by Osgood (1901) from a single female collected at Tyonek, on Cook Inlet, south-

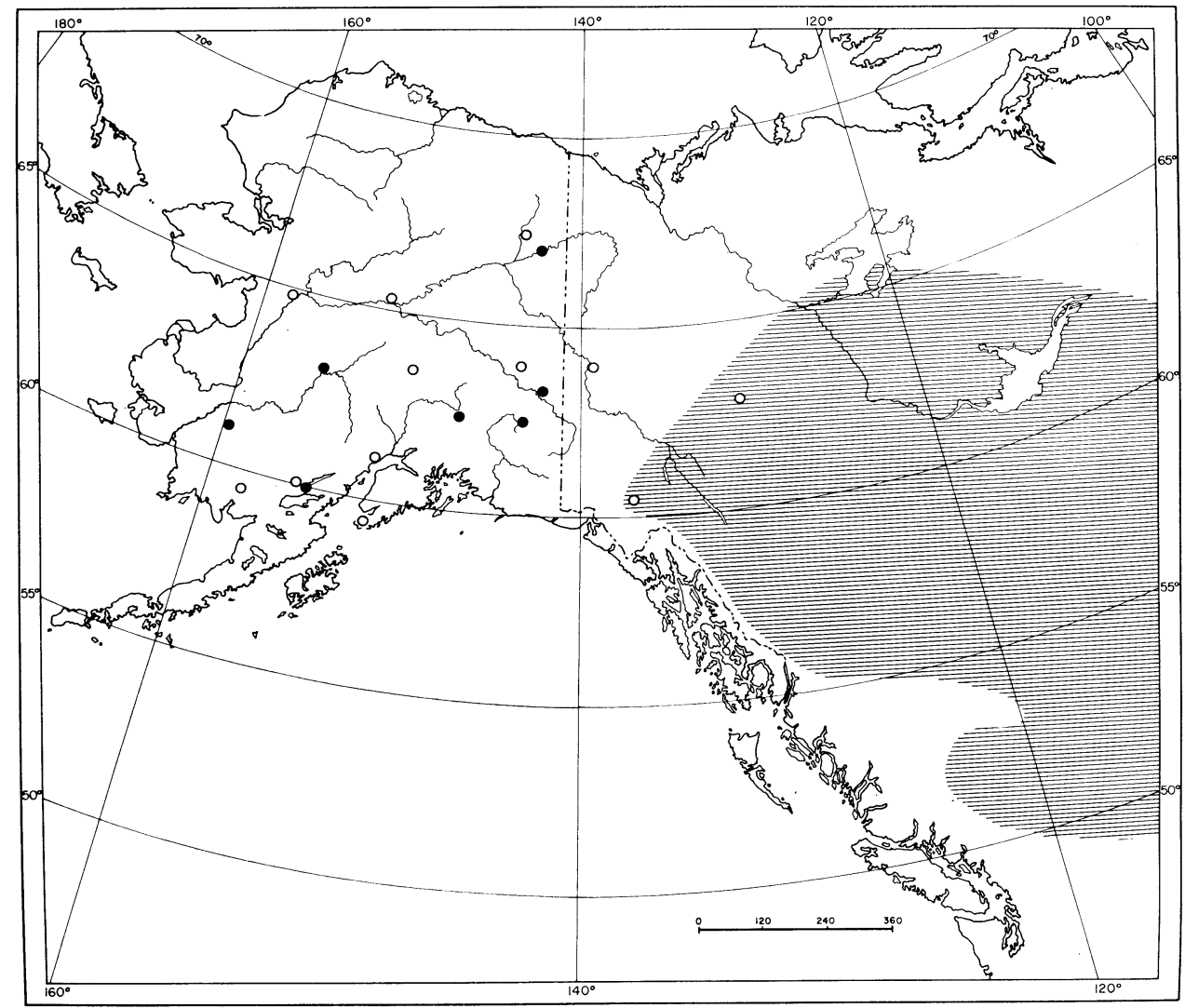

FIGURE 1. The distribution of Microsorex hoyi in northwestern North America. The distribution of $M$. hoyi intervectus according to Hall and Kelson (1959) is represented by the shaded area. Solid symbols indicate original records. 
central Alaska. Jackson (1925) recognized this shrew as being a subspecies of $M$. hoyi. The range of $M$. hoyi eximius is considered to be disjunct from that of $M$. hoyi intervectus Jackson, which is widely distributed across northern North America. According to Jackson (1928), specimens of eximius from interior Alaska somewhat resemble intervectus in cranial characteristics.

The geographic range of $H$. hoyi evidently encompasses the greater part of Alaska south of the Brooks Range. Specimens in the collections of the U. S. National Museum (in December, 1961) represent the following localities: Nulato, Tanana, Chalitna River [south branch, near portage to Swan Lake, according to Osgood (1904)], Mt. McKinley, and 80 miles up the Kakwok River. On the Kenai Peninsula, this species occurs farther south than the map of Hall and Kelson (1959, p. 51) indicates, having been collected by Allen (1904) at Barabori (= Barabara Point area), "near Homer." Allen reported this shrew also from "Moose Camp," the exact location of which cannot be determined from existing records ( $R$. G. van Gelder, personal communication), but which evidently was in the vicinity of Seldovia. $M$. hoyi has been reported by Libby (1959) from the vicinity of Big Delta and from the upper Sheenjek River region.

A specimen of $M$. hoyi, identified as belonging to the subspecies intervectus, was collected 14 miles east of Dawson, Yukon Territory, by Youngman (1964), who pointed out that the latter locality is situated about midway between the limits of the ranges of eximius and intervectus as then understood. The marginal records for intervectus in western Yukon Territory are Dezadeash Lake, near the Haines Highway, and in the north, Sheldon Lake, on the Canol Road (Rand, 1945).

All Alaskan records of $M$. hoyi as well as records from the western part of the Yukon Territory are shown in Figure 1. These data indicate that the range of $M$. hoyi eximius is not disjunct from that of $M$. hoyi intervectus.

In Alaska, M. hoyi is usually found in relatively dry, open spruce forest having a ground cover consisting of mosses and lichens along with such species as Vaccinium uliginosum, L., V. Vitis-idaea L., Ledum palustre var. decumbens Ait., and Salix spp. This shrew apparently does not occur at altitudes or latitudes beyond the limits of the spruce forest. - Arctic Health Research Laboratory, Public Health Service, U. S. Department of Health, Education, and Welfare, College, Alaska

\section{LITERATURE CITED}

Allen, J. A. 1904. Mammals collected in Alaska by the Andrew J. Stone Expedition of 1903. Bull. Amer. Mus. Nat. Hist. 20 (Art. 24) :273-292.

HaLl, E. R., and K. R. Kelson. 1959. The Mammals of North America. Vol. 1. Ronald Press Co., New York. $546+79$ pp.

Jackson, H. H. T. 1925. Two new pigmy shrews of the genus Microsorex. Proc. Biol. Soc. Wash. 38: 125-126.

JACkson, H. H. T. 1928. A taxonomic review of the American long-tailed shrews (Genera Sorex and Microsorex). N. Amer. Fauna 51, pp. 1-238. U. S. Gov't. Printing Off., Washington, D. C.

LIBBY, W. L. 1959. The distribution of some small mammals in eastern interior Alaska. J. Mammal. 40:607-609.

Jsgood, W. H. 1901. Natural history of the Cook Inlet region, Alaska. N. Amer. Fauna 21, pp. 51-87. U. S. Gov't. Printing Off., Washington, D. C.

OsGood, W. H. 1904. A biological reconnaissance of the base of the Alaska Peninsula. N. Amer. Fauna 24, pp. 9-86. U. S. Gov't. Printing Off., Washington, D. C.

Rand, A. L. 1945. Mammal investigations on the Canol Road, Yukon and Northwest Territories, 1944. Nat. Mus. Canada, Bull. 99, Biol. Ser. No. 28. 52 pp.

Youngman, P. M. 1964. Range extensions of some mammals from northwestern Canada. Nat. Hist. Papers, Nat. Mus. Canada, No. 23. 6 pp. 